\title{
ANALISIS NORMATIF KRITIS KEBIJAKAN PEMANFATAN OBLIGASI SYARIAH (SUKUK) DALAM MENUTUP DEFISIT APBN
}

\author{
Muchlis Yahya
}

\begin{abstract}
Abstrak
Tulisan ini bertujuan menganalisis keabsahan pemanfaatan sukuk (obligasi syariah) dalam menutup APBN defisit menurut kajian iE (Islamic Economics). Sebelum tabun anggaran 2008 celah APBN defisit ditutup dengan obligasi (surat utang) konvensional (surat utang berbasis suku bunga). Akan tetapi obligasi syariah yang dikenal sukuk (surat utang berbasis bagi hasil) mulai dimanfaatkan. Pemegang sukuk pada periode tertentu akan mendapatkan keuntungan melalui bagi hasil. Secara teoritik, bagi hasil hanya akan muncul jike ada kegiatan komersial/bisnis. APBN adalah dokumen yang menunjukkan kondisi keuangan pemerintah yang menyajikan informasi mengenai pendapatan, pengeluaran, aktivitas dan tujuan yang hendak dicapai. Semua pengeluaran APBN hampir dipastikan diperuntukekan kegiatan konsumtif. Suatu kegiatan konsumsi tidak akan mungkin melabirkan laba/profit. Karenanya pemanfaatan sukuk guna menutup $A P B N$ defisit tidak sesuai secara teoritik iE. Tawaran alternatifnya adalab pengintegrasian zakat pada APBN dengan berbagai pertimbangan kritis.
\end{abstract}

Kata Kunci: Sukuk, Bisnis, Konsumtif, APBN defisit, iE.

\section{Pendahuluan}

Anggaran Pendapatan dan Belanja Negara (APBN) adalah sumber pembangunan bagi setiap pemerintahan. ${ }^{1}$ Karenanya anggaran negara adalah urat nadi bagi suatu negara dalam menjalankan roda pemerintahan. ${ }^{2}$ Pengertian anggaran (budget) adalah: "A document or a collection of documents that refer to the financial condition of an organization (family, corporation, government), including

\footnotetext{
${ }^{1}$ A. S. Atmadja, Utang Luar Negeri Pemerintah Indonesia: Perkembangan dan Dampaknya. Jurnal Akuntansi dan Keuangan, 2 (1), 2004, hal. 83.

${ }^{2}$ Endah Kartikasari, Membangun Indonesia Tanpa Pajak dan Utang, Bogor: Al-Azhar Press, 2010.
}

Volume VI/Edisi 2/Oktober 2015 
Analisis Normatif Kritis Kebijakan.....

information on revenues, expenditures, activities, and purposes or goals"3 atau dokumen yang menunjukkan kondisi atau keadaan keuangan suatu organisasi [keluarga, perusahaan, pemerintah] yang menyajikan informasi mengenai pendapatan, pengeluaran, aktivitas dan tujuan yang hendak dicapai.

Bagi Negara Indonesia anggaran negara setiap tahun disusun dalam APBN dengan format berbeda-beda sesuai rezim yang berkuasa. Secara filosofi APBN adalah perwujudan dari kedaulatan rakyat sehingga penetapannya dilakukan setiap tahun dengan persetujuan legeslatif (DPR) dalam bentuk undang-undang. APBN pada dasarnya sebagai bentuk kepercayaan rakyat kepada pemerintah untuk mengelola keuangan Negara. Pengelolaannya diharapkan dapat memenuhi syarat akuntabilitas (accountability), transparan (transparency), dan kewajaran (fairness). Hampir di semua negara yang berlandaskan hukum, ketentuan mengenai anggaran belanja negara ditetapkan dalam konstitusi.

Di Indonesia, ketentuan mengenai APBN terdapat dalam UndangUndang Dasar 1945 Bab VIII, Hal Keuangan, Pasal 23 yaitu: (1) Anggaran pendapatan dan belanja negara sebagai wujud dari pengelolaan keuangan negara ditetapkan setiap tahun dengan undang-undang dan dilaksanakan secara terbuka dan bertanggung jawab untuk sebesarbesarnya kemakmuran rakyat. (2) Rancangan undang-undang anggaran pendapatan dan belanja Negara diajukan oleh Presiden untuk dibahas bersama Dewan Perwakilan Rakyat dengan memperhatikan pertimbangan Dewan Perwakilan Daerah. (3) Apabila Dewan Perwakilan Rakyat tidak menyetujui rancangan anggaran pendapatan dan belanja negara yang diusulkan oleh Presiden, Pemerintah menjalankan anggaran pendapatan dan belanja tahun yang lalu.

APBN dapat disusun dalam struktur deficit, surplus dan berimbang. Anggaran Defisit (Defisit Budget) / Kebijakan Fiskal Ekspansif adalah kebijakan membuat pengeluaran lebih besar dari pemasukan (dihitung dari penerimaan pajak). Dalam beberapa literatur didefinisikan sebagai "the gap between the public revenues and expenditures", atau selisih minus pendapatan dengan belanja publik.

${ }^{3}$ Matthews, M., Tolchinsky, P., Blanco, R., Atserias, J., Mika, P., \& Zaragoza, H., Searching through time in the New York Times. In Proc. of the 4th Workshop on Human-Computer Interaction and Information Retrieval, 2010, hal. 41-44. Liha. Juga : A. M. Rivlin, Rescuing the Budget Process. Public Budgeting \& Finance, 32(3), 2012, hal. 53-56. 
(Monzer, 1994). Kebijakan ini diperlukan guna memberi stimulus pada perekonomian dan sangat baik digunakan jika keadaan ekonomi sedang resesif. Sedangkan anggaran surplus (Surplus Budget) / kebijakan fiskal kontraktif adalah kebijakan pemerintah untuk membuat pemasukan (dihitung dari penerimaan pajak)-nya lebih besar daripada pengeluarannya. Politik anggaran surplus dilaksanakan ketika perekonomian pada kondisi yang ekspansi yang mulai memanas (overheating). Kebijakan ini diambil untuk menurunkan tekanan permintaan. Di sisi lain anggaran berimbang (Balanced Budget) adalah ditempuh ketika pemerintah menetapkan pengeluaran sama besar dengan pemasukan (dihitung dari penerimaan pajak). Tujuan politik anggaran berimbang adalah mendorong terjadinya kepastian anggaran serta meningkatkan disiplin.

Negara Indonesia hingga saat ini selalu mengambil kebijakan politik anggaran (APBN) deficit. Hal ini dapat dibuktikan pada APBN tahun 2014 yang besarnya mencapai $\mathrm{Rp} 1.842,5$ triliun dengan pendapatan pajak Rp 1.667,1 triliun. Terdapat defisit sebesar Rp 175,4 triliun. Pilihan ini dianggap penting guna menciptakan stimulus perekonomian untuk memacu pertumbuan ekonomi secara keseluruhan. Pertanyaannya adalah (1) dari sumber mana defisit anggaran (mis. anggaran tahun 2014 sebesar Rp 175,4 triliun) ditutup/peroleh?; dan (2) apakah obligasi syariah (sukuk) sebagai instrumen moneter syariah dapat dimanfaatkan untuk menutup APBN deficit?; serta konsistenkah secara teoritik iE (Islamic Economic)?

\section{Penyebab APBN Defisit}

Defisit anggaran (deficit budget) menjadi problem universal. Kondisi ini dapat terjadi di negara mana pun tanpa melihat ideologinya, baik di negara kapitalis-sekular, negara sosialis/komunis, maupun di Negara-negara muslim yang menerapkan syariah Islam secara kaffah (komprehensif). Letak perbedaannya pada faktor-faktor penyebabnya dan solusi praktis untuk mengatasi persoalan berdasarkan perspektif ideologi masing-masing.

Menurut Chapra (1992) di negara-negara kapitalis (termasuk di Dunia Islam) terdapat 4 (empat) faktor umum yang menyebabkan defisit anggaran. Keempatnya adalah belanja pertahanan yang tinggi; subsidi yang besar; belanja sektor publik (seperti belanja birokrat) yang besar dan tidak efisien; serta 
Analisis Normatif Kritis Kebijakan.....

korupsi dan pengeluaran yang boros. Secara garis besar penyebab terjadinya anggaran deficit dapat disimpulakan karena (1) mempercepat pertumbuhan ekonomi; (2) rendahnya daya beli Masyarakat; (3) pemerataan pendapatan masyarakat. Melemahnya nilai tukar menjadi penyebab ke-4, disusul kemudian (5) pengeluaran akibat krisis ekonomi; (6) realisasi yang menyimpang dari rencana; (7) pengeluaran karena inflasi. ${ }^{4}$ Ketujuh factor di atas dapat dijelaskan sebagai berikut:

\section{Mempercepat Pertumbuhan Ekonomi}

Untuk mempercepat pembangunan diperlukan investasi yang besar dan dana yang besar pula. Apabila dana dalam negeri tidak mencukupi, biasanya negara melakukan pilihan dengan meminjam ke luar negeri. Pilihan ini diambil untuk menghindari pembebanan warga negara apabila kekurangan itu ditutup melalui penarikan pajak. Negara memang dibebani tanggung jawab yang besar dalam meningkatkan kesejahteraan warga negaranya. Beban ini meliputi pembangunan program-program, seperti :

a. Program untuk pertumbuhan ekonomi, seperti jalan, jembatan, listrik, pelabuhan.

b. Program yang berkaitan dengan bidang hankam.

c. Pembangunan bidang hukum, seperti proyek-proyek pengadilan, lembaga pemasyarakatan

d. Program bidang sosial, pendidikan, kesehatan, seperti sekolah, rumah sakit, panti asuhan.

e. Program yang berkaitan dengan pemerataan pendapatan, seperti program transmigrasi, pembangunan daerah, dll.

f. Program yang menangani masalah kemiskinan, seperti PPK, P3DT, dsb.

Semua pekerjaan tersebut memerlukan biaya yang besar, dan diantaranya harus dilaksanakan oleh Negara. Pihak swasta/masyarakat tidak mungkin membangun program-program seperti pada item a hingga $f$.

${ }^{4}$ David N., Hyman. Public Finance, London: Dryden Press, 1999, hal. 446. 
2. Rendahnya Daya Beli Masyarakat

Masyarakat di negara berkembang seperti Indonesia yang mempunyai pendapatan per kapita rendah dikenal mempunyai daya beli yang rendah pula. Sedangkan harga barang-barang dan jasa-jasa yang dibutuhkan sangat tinggi karena sebagian produksinya mempunyai komponen impor. Kondisi ini membuat masyarakat yang berpendapatan rendah tidak mampu membeli barang dan jasa, seperti listrik, sarana transportasi, BBM, dan lain sebagainya. Apabila dibiarkan saja menurut mekanisme pasar, maka barangbarang tersebut pasti tidak mungkin terbeli masyarakat. Masyarakat akan tetap terpuruk. Oleh karena itu, negara memerlukan pengeluaran untuk mensubsidi barang-barang tersebut agar masyarakat miskin bisa ikut menikmati.

3. Pemerataan Pendapatan Masyarakat

Pengeluaran ekstra juga diperlukan dalam rangka menunjang pemerataan di seluruh wilayah. Indonesia mempunyai wilayah sangat luas dengan tingkat kemajuan yang berbeda-beda di masing-masing wilayah. Untuk mempertahankan stabilitas politik, persatuan dan kesatuan bangsa negara harus mengeluarkan biaya subsidi transportasi ke wilayah yang miskin dan terpencil. Kebijakan ini mendorong agar masyarakat di wilayah itu dapat menikmati hasil pembangunan yang tidak jauh berbeda dengan wilayah yang lebih maju. Kegiatan itu misalnya dengan memberi subsidi kepada pelayaran kapal perintis yang menghubungkan pulau-pulau yang terpencil, sehingga masyarakat mampu menjangkau wilayah-wilayah lain dengan biaya yang sesuai dengan kemampuannya.

4. Melemahnya Nilai Tukar

Indonesia yang sejak tahun 1969 memutuskan melakukan pinjaman luar negeri akan mengalami masalah apabila ada gejolak nilai tukar setiap tahunnya. Masalah ini disebabkan karena nilai pinjaman dihitung dengan valuta asing, sedangkan pembayaran cicilan pokok dan bunga pinjaman dihitung dengan rupiah. Apabila nilai tukar rupiah menurun terhadap mata uang dollar AS, maka yang akan dibayarkan juga membengkak. Sebagai contoh, APBN tahun 2015 disusun dengan asumsi kurs rupiah terhadap dollar AS sebesar Rp. 9.500,-, tetpi dalam perjalanan tahun anggaran telah mencapai angka Rp. 12.500,- lebih per US\$ 1.00. Apa artinya? Bahwa 
pembayaran cicilan pokok dan bunga pinjaman yang diambil dari APBN bertambah lebih dari apa yang dianggarkan semula.

5. Pengeluaran Akibat Krisis Ekonomi

Krisis ekonomi Indonesia yang terjadi tahun 1997 mengakibatkan meningkatnya pengangguran dari 34,5 juta orang pada tahun 1996, menjadi 47,9 juta orang pada tahun 1999.5 Sedangkan penerimaan pajak menurun akibat menurunnya sektor-sektor ekonomi sebagai dampak krisis. Di sisi lain negara harus bertanggung jawab untuk menaikkan daya beli masyarakat yang tergolong miskin. Dalam hal ini negara terpaksa mengeluarkan dana ekstra untuk program-program kemiskinan dan pemberdayaan masyarakat terutama di wilayah pedesaan yang miskin itu.

6. Realisasi yang Menyimpang dari Rencana

Apabila realisasi penerimaan negara meleset dibanding rencana, atau dengan kata lain penerimaan negara tidak dapat mencapai sasaran seperti apa yang direncanakan, maka berarti beberapa kegiatan, proyek, atau program harus dipotong. Pemotongan proyek tidak begitu mudah semudah membalik telapak tangan. Hal ini karena untuk mencapai kinerja pembangunan, suatu proyek tidak bisa berdiri sendiri, tetapi ada kaitannya dengan proyek lain. Kalau hal ini terjadi, maka negara harus menutup kekurangan agar kinerja pembangunan dapat tercapai sesuai dengan rencana semula.

7. Pengeluaran karena Inflasi

Penyusunan anggaran negara pada awal tahun didasarkan menurut standar harga yang telah ditetapkan. Harga standar dalam perjalanan tahun anggaran tidak dapat dijamin ketepatannya. Apabila terjadi inflasi, maka biaya pembangunan program kegiatan akan meningkat, sedangkan anggarannya tetap sama. Kondisi ini akan berakibat pada menurunnya kuantitas dan kualitas program, sehingga anggaran negara perlu direvisi. Anggaran negara yang telah tercantum terlalu rinci dalam dokumen anggara menyulitkan pelaksana untuk menyesuaikan dengan kenaikan harga barang yang melampaui harga standar. Melaksanakan pembangunan proyek yang melampaui standar yang telah ditentukan atau mengurangi volumenya akan dipersalahkan oleh Badan Pengawas Keuangan (BPK) dan/atau KPK.

${ }^{5}$ BPS (Badan Pusat Statistik), Statistik Indonesia, Jakarta: 1999, hal. 595. 
Akibatnya negara terpaksa akan mengeluarkan dana untuk eskalasi dalam rangka menambah standar harga.

\section{Dampak Kebijakan APBN Defisit terhadap Ekonomi Makro}

Pertanyaan penting dalam menganalisis dampak kebijakan APBN adalah seberapa penting membicarakan anggaran defisit? Mengapa defisit anggaran negara merupakan momok yang sangat ditakuti?

Dapatlah ditamsilkan, bahwa defisit anggaran itu ibaratnya seperti penyakit hipertensi yang dampaknya bisa mempengaruhi kerja jantung, ginjal, mata, otak, yang berakibat kelumpuhan. Demikian pula defisit anggaran juga berdampak pada beberapa variabel ekonomi makro, antara lain adalah tingkat bunga; neraca pembayaran; tingkat inflasi; konsumsi dan tabungan; tingkat pengangguran; dan tingkat pertumbuhan.

1. Dampak Terhadap Tingkat Bunga

Defisit anggaran ditandai dengan kurangnya pembiayaan pengeluaran negara karena kurangnya penerimaan yang berasal dari pajak. Untuk memenuhi kebutuhan masyarakat dalam meningkatkan anggaran pembangunan maupun rutin, negara memerlukan penambahan modal. Kondisi ini berarti permintaan terhadap uang meningkat. Bunga yang merupakan harga modal akan mengalami tingkat keseimbangan yang lebih tinggi, atau tingkat bunga akan meningkat.

2. Dampak Terhadap Neraca Pembayaran

Dalam ekonomi terbuka, defisit anggaran dapat mempengaruhi posisi ekspor dan impor dari dan ke manca negara. Dengan meningkatnya tingkat bunga, investasi dalam negeri akan menurun. Kondisi ini berarti peluang modal asing cenderung masuk mengalir ke dalam negeri untuk memenuhi kebutuhan investasi dalam negeri. Apabila ini terjadi, maka deficit anggaran mempunyai dua dampak yang berkaitan. Pertama, defisit anggaran akan meningkatkan defisit neraca pembayaran. kedua, membengkaknya defisit neraca pembayaran akan menurunkan nilai tukar uang dalam negeri 
terhadap mata uang asing. ${ }^{6}$ Sehingga menurunnya nilai rupiah terhadap valuta asing selama ini bukan saja disebabkan karena faktor psikologis, tetapi juga faktor teknis.

3. Dampak Terhadap Tingkat Inflasi

Pengeluaran negara yang melebihi penerimaannya berarti anggaran ekspansif. Kondisi ini mendorong kecenderungan terhadap kenaikan hargaharga umum (inflasi). Mengapa? Karena pengeluaran negara yang digunakan untuk pembangunan proyek-proyek dengan biaya besar dan berjangka lama belum dapat menghasilkan dalam waktu yang cepat. Padahal negara telah melakukan pengeluaran-pengeluaran, antara lain untuk upah buruh yang berakibat meningkatnya daya beli masyarakat. Dengan meningkatnya daya beli masyarakat di satu pihak dan belum ada output yang dihasilkan di lain pihak akan mendorong harga-harga umum akan meningkat yang berujung menculnya inflasi. Dalam masa pembangunan yang menggebu-gebu sulit bisa dihindarkan keadaan inflasi ini.

4. Dampak Terhadap Konsumsi dan Tabungan

Inflasi yang diakibatkan karena defisit anggaran akan mengurangi pendapatan riil masyarakat. Pengurangan pada pendapatan riil masyarakat akan berakibat pada pengurangan konsumsi maupun tabungan. Tabungan sangat penting sekali untuk mendorong investasi. Apabila pendapatan riil menurun berarti tingkat konsumsi dan tabungan riil juga menurun. Sedangkan tingkat tabungan riil akan berpengaruh terhadap tingkat investasi. Penurunan tingkat tabungan mendorong penurunan investasi.

5. Dampak Terhadap Penggangguran

Pengganguran berarti penurunan tingkat kesempatan kerja. Kesempatan kerja tergantung pada besarnya investasi yang dilakukan baik oleh negara maupun masyarakat. Naiknya tingkat bunga akibat dari anggaran negara yang defisit akan berdampak menurunnya gairah untuk investasi. Hal ini berarti banyak proyek-proyek maupun perluasan proyek

${ }^{6}$ Daniel Shaviro, Do Deficits Matter?, Chicago: The University of Chicago Press, 1997, hal. 193. Lih. Juga : I. Zuhroh \& Kaluge, D., Dampak Pertumbuhan Nilai Tukar Riil Terhadap Pertumbuhan Neraca Perdagangan Indonesia (Suatu Aplikasi Model Vector Autoregressive, Var). Journal of Indonesian Applied Economics, 1(1), 2012. 
yang sudah ada tidak dapat dibangun, sehingga berakibat pada pemecatan tenaga kerja atau kurangnya tenaga kerja baru yang masuk dalam lapangan kerja. Dengan demikian deficit anggaran secara langsung berakibat pada kenaikan peningkatan tingkat penggangguran.

6. Dampak Terhadap Tingkat pertumbuhan

Pertumbuhan ekonomi yang meningkat adalah akibat dari meningkatnya investasi, baik dari negara maupun masyarakat. Peningkatan investasi bisa terjadi karena situasi keamanan yang kondusif, dan tingkat bunga yang rendah. Tetapi apabila perubahan variabel-variabel tersebut berlawanan dengan yang disebutkan diatas, terutama tingkat bunga yang tinggi akibat defisit anggaran, maka tingkat pertumbuhan yang tinggi tidak akan tercapai. Dapat dikatakan defisit anggaran mengakibatkan pada penurunan tingkat pertumbuhan.

\section{Solusi Menambal Anggaran Defisit}

Dilihat dari sisi manajemen APBN, negara harus dapat menutup kekurangan pendapatan. Secara teoritis menutup defisit APBN dapat dilakukan secara mudah. Prinsipnya dapat ditanggulangi dengan cara menambah di sisi penerimaan atau mengurangi di sisi pengeluaran. Masalahnya ketika pilihan kebijakan memilih menambah sisi penerimaan, penerimaan yang mana, jenis pajak yang mana. Apabila pilihan jatuh pada mengurangi pengeluaran, maka jenis pengeluaran yang mana. Pilihan terakhir ini kadangkadang dapat diperdebatkan oleh para politisi, karena mereka khawatir tidak populer lagi di mata masyarakat. Itulah solusi yang sulit untuk dipecahkan.

\section{a. Sisi pengeluaran}

Kebijakan sisi pengeluaran dapat ditempuh dengan:

1. Mengurangi subsidi.

Satu sisi pengurangan subsidi akan mengurangi beban pemerintah, tetapi di sisi lain justeru menambah beban ekonomi masyarakat. Kebijakan ini akan dinilai sebagai tidak pro rakyat jelata. Kenaikan harga BBM premium dan solar dalam rangka mengurangi beban subsidi terhadapnya dari Rp. 4.500,- menjadi Rp. 6.500,- (untuk jenis 
Analisis Normatif Kritis Kebijakan....

premium) dan menjadi Rp. 5.500,- (untuk jenis solar) pada 22 Juni 2013 menjadi sebuah contoh kebijakan paling gambling. Kebijakan ini mengundang reaksi masyarakat. ${ }^{7}$ Selang beberapa bulan harga BBM naik kembali ke posisi harga Rp. 8500,- untuk premium, dan Rp. 7.600,- untuk solar, kemudian turun lagi ke posisi harga Rp. 7.200,untuk premium, dan Rp. 6.600,- untuk solar.

2. Penghematan pada setiap pengeluaran rutin maupun pembangunan.

Tempuhan penghematan pada pengeluaran rutin dilakukan oleh departemen teknis, misalnya untuk pengeluaran listrik, telepon, alat tulis, perjalanan dinas, rapat-rapat, seminar, dan sebagainya tanpa mengurangi kinerja dari departemen teknis yang bersangkutan. Pengurangan belanja sebesar 100 Triliyun rupiah pada APBN 2014 menjadi contoh actual. Kebijakan ini diambil karena pemerintah tidak cukup mampu mencari solusi menutup defisit anggaran. ${ }^{8}$

3. Menyeleksi sebagian pengeluaran-pengeluaran pembangunan.

Pengeluaran pembangunan yang berupa proyek-proyek pembangunan diseleksi menurut prioritasnya. Misalnya proyek-proyek yang cepat menghasilkan akan tetap didorong dan anggarannya tidak dipangkas. Sedangkan proyek-proyek yang menyerap biaya besar dan penyelesaiannya dalam jangka waktu yang lama ditunda pelaksanaannya

4. Mengurangi pengeluaran program tidak produktif dan tidak efisien

Kategori tidak produktif adalah program-program yang tidak mendukung pertumbuhan sektor riil, tidak mendukung kenaikan penerimaan pajak, dan tidak mendukung kenaikan penerimaan devisa (IMF, 1995). Pemotongan program-program ini harus dilakukan dengan hati-hati. Pemotongan pengeluaran tanpa memperbaiki

7 Tempo.co. BISNIS, Kenaikan Harga BBM Diumumkan Jumat, 2013 http:// www.tempo.co/read/news/2013/06/20/090489858/Kenaikan-Harga-BBM-Diumumkan-Jumat (diakses 4 Juni 2014).

8 Kementerian Keuangan Republik Indinesia. 2014. Revisi APBN 2014 Ditujukan Untuk Fiskal yang Sehat. http://www.kemenkeu.go.id/Berita/revisi-apbn-2014-ditujukan-untuk-fiskal-yangsehat. (Diakses 4 Juni 2014). 
produktivitas program berarti akan ada kecenderungan menurunnya kualitas dan kuantitas output.

5. Menurunkan gaji pegawai

Kebijakan menurunkan gaji pegawai akan berdampak pada penurunan pendapatan yang berakibat pada menurunnya daya beli. Kebijakan ini juga akan menyulut instabilitas social politik.

Memilih mengambil kebijakan pengurangan terhadap sisi-sisi pengeluaran sangat sulit, kecuali dalam kondisi luar biasa (dhorurot). Dampak negative dari kebijakan ini akan sangat besar. Biaya sosialnya sangat tinggi. Karenanya banyak negara yang memilih menggunakan kebijakan sisi penerimaannya.

\section{b. Sisi penerimaan}

Kebijakan sisi penerimaan dapat ditempuh dengan:

1. Meminjam dari perbankan dalam negeri.

Kebijakan ini sesungguhnya pencetakan uang baru. Kondidi ini mendorong uang yang beredar pada masyarakat (money supply) meningkat. Dampak terhadap pertambahnya penawaran uang yang tidak diimbangi dengan jumlah barang yang diproduksi akan mengakibatkan kenaikan harga-harga umum atau inflasi.

2. Meminjam dari luar negeri

Pinjaman dari luar negeri mungkin akan menghadapi kritik sebagian masyarakat. Pinjaman luar negeri dianggap akan membebani anak cucu di kemudian hari. Akan tetapi selama digunakan untuk proyekproyek yang produktif dan efisien seperti pembangunan sarana dan prasarana ekonomi, generasi penerus telah mempunyai pondasi yang kuat untuk membangun proyek-proyek selanjutnya. Sedangkan pembayaran cicilannya dapat diambil dari perpajakan yang akan ditarik dari perusahaan-perusahaan yang telah mapan dari pinjaman sebelumnya.

3. Meningkatkan penerimaan pajak, langsung maupun pajak tidak langsung. 
Kebijakan menggenjot penerimaan pajak dengan meningkatkan tarif pajak akan menambah penerimaan negara. Akan tetapi tempuhan ini akan berdampak pada pendapatan masyarakat (produsen maupun RT). Jika ini terus menerus dilakukan, maka berkemungkinan akan menurunkan semangat berusaha utamanya pada sektor industriindustri menengah ke atas. Karena mereka berpikir penghasilannya akan lebih banyak lari ke tangan pemerintah. Ujung akhirnya adalah pengangguran.

4. Mencetak uang

Alternatif ini tidak popular. Penambahan anggaran dari mencetak uang berarti akan menambah uang yang beredar yang berdampak pada inflasi. Kondisi bertambah parah jika masyarakat membelanjakannya untuk kegiatan-kegiatan tidak produktif atau tidak efisien alias konsumtif.

5. Meminjam kepada masyarakat dengan cara menerbitkan obligasi.

Di satu sisi penjualan obligasi pemerintah akan menyerap uang masyarakat dan menambah penerimaan negara. Akan tetapi penyerapan uang dari masyarakat berakibat mengurangi jumlah uang yang beredar di masyarakat yang berdampak pada penurunan harga. Namun demikian, kebijakan ini berdampak pada mengurangi tabungan masyarakat di sector perbankan. Tabungan masyarakat yang terkumpul di sektor perbankan sangat diperlukan oleh produsen dan masyarakat secara luas untuk investasi.

\section{A. Kajian Kritis}

Solusi sisi pengeluaran dan sisi penerimaan tersebut di atas dilakukan dengan skema konvensional. Semua aktivitas dijalankan dengan basis bunga (i) sebagai harga uang. Masyarakat pemilik uang pada kurun tertentu akan mendapatkan tambahan uang sebagai manipestasi harga/bunga dari uang yang dipinjamkan kepada pemerintah. Munculnya tambahan uang sudah dipastikan di depan tanpa memperhitungkan kegiatan komersialnya lancar atau hancur, mendapat keuntungan (profit) 
atau kerugian (loss/risk). Mereka memastikan untung sebagai kondisi "harus".

Disamping skema konvensional ternyata muncul skema lain, yakni kebijakan moneter syari'ah yang berbasis bagi hasil/BH. Skema terakhir ternyata telah dijadikan solusi berbagai pemerintahan termasuk pemerintahan Indonesia untuk menutup APBN defisit. Pemerintah Indonesia sudah menjalankannya dengan penjualan obligasi syariah (sebagai instrument moneter syariah). Tahun 2013, mislanya, pemerintah telah berhasil menyerap dana masyarakat melalui "penjualan" obligasi sayariah/sukuk sebesar Rp. 8 triliun,-. ${ }^{9}$ Dana tersebut telah dimanfaatkan untuk menutup defisit APBN 2013.

Penerbitan Obligasi Syariah (sukuk) sebagai bagain Open Market Operation.

Obligasi syariah (atau disebut sukuk) adalah surat berharga jangka panjang berdasarkan prinsip syari'ah yang dikeluarkan pihak emiten. Sukuk merupakan instrument moneter syariah. Emiten berkewajiban membayar pendapatan atau keuntungan kepada pemegang obligasi syari'ah berupa bagi hasil / margin / fee serta membayar kembali dana obligasi pada saat jatuh tempo. ${ }^{10}$ Munculnya hasil atau keuntungan (revenue / profit) diakibatkan adanya kegiatan bisnis. Keuntungan dan/atau hasil inilah yang dapat dibagikan (share) kepada pihak-pihak shobibul maal dan mudhorib.

\section{Teori Bisnis}

Secara historis kata bisnis berasal dari bahasa Inggris business, dari kata dasar busy yang berarti "sibuk". Makna konotasinya adalah sibuk mengerjakan aktivitas dan pekerjaan yang mendatangkan keuntungan. Dalam ilmu ekonomi, bisnis adalah suatu organisasi yang menjual barang atau jasa kepada konsumen untuk mendapatkan laba. Bisnis dibentuk untuk mendapatkan profit dan meningkatkan kemakmuran para pemiliknya. Pemilik dan operator dari sebuah bisnis mendapatkan imbalan sesuai dengan waktu, usaha, atau kapital yang mereka berikan.

9 Burhani, Ruslan. 2013. Lelang obligasi negara serap dana Rp.8 triliun. ANTARANEWS.com. Rabu, 6 November http://www.antaranews.com/ berita/ 403895/lelangobligasi negara-serap-dana-rp8-.triliun (diakses 20-04-2014)

${ }^{10}$ Dewan Syariah Nasional MUI, 2002. Fatwa DSN: No: 32/DSN-MUI/IX/2002. 
Secara etimologi, bisnis berarti keadaan dimana seseorang atau sekelompok orang sibuk melakukan pekerjaan yang menghasilkan keuntungan. Bisnis adalah kegiatan yang dilakukan oleh individu dan sekelompok orang (organisasi) yang menciptakan nilai (create value) melalui penciptaan barang dan jasa (create of good and service) untuk memenuhi kebutuhan masyarakat dan memperoleh keuntungan melalui transaksi. Keuntungan muncul karena ada aktifitas BISNIS.

Kegiatan bisnis yang dilakukan perusahaan dapat berbentuk perseroan terbatas (PT) ataupun berbentuk firma. Kegiatan bisnis dapat dijalankan pelaku swasta (perseorangan dari masyarakat) maupun badan pemerintah. Kegiatan bisnis yang dilakukan perseorangan lebih berfokus murni mencari keuntungan. Sedangkan kegiatan bisnis yang dilakukan badan usaha pemerintah/negara lebih dimaksudkan untuk meningkatkan kesejahteraan masyarakat sesuai dengan pasal 33 ayat 1 UUD 1945 meskipun tidak sama sekali meninggalkan visi profit oriented. Kegiatan bisnis yang dilakukan pemerintah dapat dilaksanakan dalam bentuk BUMN / BUMD, Perum, maupun PD (Perusahaan Daerah) seperti PD Pasar. $\mathrm{BKK} / \mathrm{BPR}$.

Karenya dalam bisnis terjadi aktifitas komersial atau usaha perdagangan. Aktifitas komersial dapat berwujud produksi, distribusi (tetapi tidak konsumsi). Produksi adalah menciptakan barang/jasa. Produksi adalah proses mengubah sumber daya input menjadi output (barang atau jasa). Sedangkan distribusi adalah memindah barang/jasa dari tiik satu ke titik lain. Keduanya adalah aktifitas komersial yang memberikan konsekuensi munculnya keuntungsn dan atau kerugian.

Rangkaian kegiatan bisnis yang telah terdeskripsikan di atas mengandung beberapa aspek. Pertama, kegiatan individu dan/atau kelompok. Kedua, penciptaan nilai. Ketiga, penciptaan barang dan jasa, dan keempat adalah munculnya keuntungan dan/atau (kemungkinan) kerugian melalui transaksi.

Aspek kegiatan individu dan/atau kelompok mengandung pengertian, bahwa aktifitas individu dan kelompok merupakan kunci dari bergeraknya proses bisnis. Perputaran bisnis selalu bergantung pada 
pemasaran. Sedangkan pemasaran sangat bergantung dengan kemampuan individu maupun kelompok untuk bergerak berpindah dari satu tempat ke tempat lainnya guna menggerakkan calon konsumen menjadi konsumen sesungguhnya. ${ }^{11}$

Bisnis dalam arti luas dapat dipahami sesbagai suatu istilah umum yang menggambarkan suatu aktivitas institusi yang memproduksi barang dan jasa dalam kehidupan sehari-hari. ${ }^{12}$ Menurut Buchori Alma (2004) bisnis adalah sejumlah total usaha yang meliputi pertanian, produksi, konstruksi, distribusi, transportasi, komunikasi, usaha jasa dan pemerintah, yang bergerak dalam bidang membuat dan memasarkan barang dan jasa kepada konsumen. Menurut Louis E. Boone, ${ }^{13}$ bisnis (bussines) terdiri dari seluruh aktivitas dan usaha untuk mencari keuntungan dengan menyediakan barang dan/atau jasa yang dibutuhkan bagi sistem perekonomian. Beberapa bisnis memproduksi barang berwujud sedangkan lainnya memproduksi jasa.

Dengan demikian bisnis merupakan tindakan individu atau sekelompok orang yang menciptakan nilai melalui penciptaan barang dan jasa. Kegiatan tersebut dilakukan untuk memenuhi kebutuhan masyarakat di satu sisi dan memperoleh keuntungan melalui transaksi komersial di sisi lain.

Dari sisi varian jenis bisnis dapat dikelompokkan menjadi ekstraktif yaitu kegiatan usaha dalam bidang pertambangan atau menggali bahanbahan tambang yang terkandung di dalam perut bumi. Kedua, agraria yaitu kegiatan bisnis bidang pertanian. Ketiga, industri yaitu bisnis yang bergerak dalam bidang industri. Keempat, jasa yaitu bisnis yang bergerak dalam bidang jasa yang menghasilkan produk-produk yang tidak berwujud. ${ }^{14}$

11 Chandra, A dan Hatane Semuel., M.S., Ritzky Karina M. R. Brahmana, S.E., M.A., Pengaruh Aktivitas Customer Relationship Marketing Terhadap Kepuasan Pelanggan Melalui Manfaat Penerapan Relationship Marketing di Excelso Galaxy mall Surabaya. Jurnal Strategi Pemasaran, 1(2), 2013, hal. 1-8.

12 Amirullah, B. H, Pengantar Manajemen. Yogyakarta: Graha Ilmu, 2004, hal. 2

13 Boone, L. E., \& Kurtz, D. L., Marketing contemporâneo. Cengage Learning, 2009, hal. 5

${ }^{14}$ Gitosudarmo, Indriyo \& Agus Mulyono, Prinsip Dasar Manajemen, Yogyakarta: BPFE, 1999, hal. 3. 
Semua kegiatan komersial tersebut dapat bergerak karena adanya elemen bisnis yang merupakan sumber daya bagi sebuah bisnis. Elemen bisnis terdiri dari modal, bahan material, sumberdaya manusia (SDM), dan keterampilan manajeen. Modal yaitu sejumlah uang yang digunakan dalam menjalankan kegiatan-kegiatan bisnis. Bahan material yaitu bahan-bahan yang terdiri dari sumber daya alam, yakni tanah, kayu, mineral, dan minyak. Sumber daya alam tersebut disebut sebagai faktor produksi yang dibutuhkan dalam melaksanakan aktivitas bisnis untuk diolah dan menghasilkan barang dan jasa yang dibutuhkan masyarakat.

Sedangkan sumber daya manusia adalah sumber daya yang berkualitas yang diperlukan untuk kemajuan sebuah bisnis. Keterampilan manajemen menjadi bagian penting pada SDM yang bagus. Keberadaannya menjadi pra syarat bagi suatu bisnis yang sukses. Bisnis yang sukses adalah bisnis yang dijalankan dengan manajemen yang efektif. Sistem manajemen yang efektif adalah sistem yang dijalankan berdasarkan prosedur dan tata kerja manajemen yang baik. Bekerjanya elemen bisnis secara simultan dan efektif akan menghasilkan produk yang berkualitas dan pada akhirnya berdampak kepada ketertarikan konsumen sebagai pilar utama bisnis.

Kemenarikan terhadap suatu barang/atau jasa tidak akan bertahan lama di hadapan konsumen jika tidak ada inovasi. Di sisi lain inovasi hanya akan dapat muncul pada SDM (karyawan, dewan komisaris, dan pemegang saham) yang memiliki jiwa kewirausahaan handal di semua tingkatan manajemen.

Tiap orang tertarik kepada kewirausahaan kerena berbagai imbalan yang terdiri dari laba, kebebasan, dan kepuasan dalam menjalani hidup. Wirausaha mengharapkan hasil yang tidak hanya mengganti kerugian waktu dan uang yang diinvestasikan, tetapi memberikan imbalan yang pantas bagi resiko dan inisiatif yang mereka ambil. Dengan demikian imbalan berupa laba/pendapatn merupakan motifasi kuat bagi wirausaha tertentu. Laba adalah salah satu cara dalam mempertahankan nilai perusahaan. Kesinambungan laba dalam jangka lama akan dicapai hanya jika penjualan produk dapat bertahan dalam jangka lama. Kondisi tersebut 
hanya akan dapat terealisasi jika inovasi produk muncul pada setiap periode.

Analisis di atas dapat diterapkan dalam mengkaji kegiatan usaha mencari dana penutup APBN defisit. Prinsip APBN adalah konsumtif. APBN diperlukan untuk membiayai belanja negara, membayar gaji pegawai negara, dan pengeluaran transfer payments. Ketiga kegiatan pengeluaran pemerintah masuk dalam kategori aktifitas konsumsi. Sedangkan prinsip konsumsi adalah menghabiskan barang. Karenanya kegiatan konsumtif tidak akan memunculkan keuntungan ekonomis yang dapat dibagi kepada para pihak.

Oleh karenanya pemanfaatan obligasi syariah untuk membiayai APBN tidak sesuai dengan teori ilmu ekonomi Islam (iE). Namun jika APBN dipahami tidak saja berupa kegiatan konsumtif belaka, namun mencakup kegiatan produktif (terdapat sisi belanja modal), maka obligasi syariah (sukuk) yang dikeluarkan pemerintah guna menutup defisit penerimaan APBN dapat dipertanggung jawabkan secara keilmuan ekonomi Islam (iE). Akan tetapi masih dapat diperdebatkan tentang belanja modal yang benar-benar akan menghasilkan suatu keuntungan komersial. Belanja modal hanyalah istilah teknis yang dipergunakan untuk pembelian barang-barang tidak habis pakai. Pertanyaan berikutnya adalah apakah bagi hasil yang diterima pemilik sukuk benar-benar keuntungan/hasil untuk dari belanja-belanja barang dimaksud (?).

\section{Kesimpulan}

1. Jika APBN dipahami sebagai semata-mata kegiatan konsumtif, maka obligasi syariah yang dikeluarkan pemerintah sebagai salah satu instrument moneter syariah guna mencari tambahan dana penutup APBN defisit tidak konsisten secara teoritik dalam iE.

2. Jika APBN dipahami sebagai tidak semata-mata kegiatan konsumtif (karena terdapat sisi belanja modal), maka obligasi syariah yang dikeluarkan pemerintah sebagai salah satu instrument moneter guna mencari tambahan dana penutup APBN defisit adalah konsisten secara teoritik dalam iE. Meskipun hal ini masih diperdebatkan. 


\section{Saran}

1. Perlu pembahasan ulang dan lebih mendalam terhadap materi fatwa Dewan Syariah Nasional Nomor: 32/DSN-MUI/IX/2002, tentang Obligasi Syari'ah. Hal ini diperlukan untuk lebih memperjelas hukum dari keperuntukan aplikasi obyek yang berbeda-beda.

2. Mengingat $\pm 83 \%$ penduduk Indonesia adalah Muslim yang secara otomatis sebagai mayoritas penerima sisi pengeluaran APBN, sudah waktunya untuk mengintegrasikan dana zakat dalam struktur APBN deficit. Kondisi ini sangat dimungkinkan disamping karena sudah ada Undang Undang No. 23 tentang Pengelolaan Zakat, juga potensi zakat yang fantastis. Pada tahun 2013 potensinya telah mencapai kisaran 217 triliun (Baznas, 2013) dan penerimaan Baznas pada tahun 2014 mencapai Rp. 175,4 triliun. Dengan demikian pengelolaan zakat akan lebih efektif, terarah dan akuntabel. Mungkin perdebatan akan mengarah pada karena penerima bukan semuanya muslim. Problem ini dapat dijelaskan bahwa sisi pengeluaran besaran dana zakat adalah untuk aspek transfer payment murni yang akan diterima oleh mustahik muslim. Besaran sisi pengeluaran APBN yang diterima mustahik muslim adalah sama persis dengan jumlah sisi penerimaan APBN dari dana zakat. 


\section{DAFTAR PUSTAKA}

Atmadja, A. S. 2004. Utang Luar Negeri Pemerintah Indonesia: Perkembangan dan Dampaknya. Jurnal Akuntansi dan Keuangan, 2(1).

Amirullah, B. H. 2004. Pengantar Manajemen. Graha Ilmu. Yogyakarta.

Baznas (Badan Amil Zakat Nasional). 2013. "Potensi zakat kita sangat besar Rp 217 triliun hanya saja yang terserap baru sekitar satu persen saja," Workshop Internasional Zakat, Infak dan Perekonomian Islam. Bogor, Senin (29/4).

Boone, L. E., \& Kurtz, D. L. 2009. Marketing contemporâneo. Cengage Learning.

Burhani, Ruslan. 2013. Lelang obligasi negara serap dana Rp.8 triliun. ANTARANEWS.com. $\quad$ Rabu, 6 November http://www.antaranews.com/ berita/ 403895/lelang-obligasi negara-serap-dana-rp8-.triliun (diakses 20-04-2014)

BPS (Badan Pusat Statistik). 1999. Statistik Indonesia, Jakarta.

Buchari, A. 2004. Manajemen Pemasaran dan Pemasaran Jasa. Alfabeta, Bandung.

Chapra, Umer. 1992. Islam and the Economic Challenge. Islamic Foundation.

Chandra, A dan Hatane Semuel., M.S., Ritzky Karina M. R. Brahmana, S.E., M.A. 2013. Pengaruh Aktivitas Customer Relationship Marketing Terhadap Kepuasan Pelanggan Melalui Manfaat Penerapan Relationship Marketing di Excelso Galaxy mall Surabaya. Jurnal Strategi Pemasaran, 1(2).

David N., Hyman. 1999. Public Finance, Dryden Press, London.

Dewan Syariah Nasional MUI, 2002. Fatwa DSN: No: 32/DSNMUI/IX/2002.

Gitosudarmo, Indriyo \& Agus Mulyono. 1999. Prinsip Dasar Manajemen, Yogyakarta: BPFE.

IMF. 1995. Unproductive Public Expenditure, Fiscal Affair Department IMF, Washington DC,

Kartikasari, Endah. 2010. Membangun Indonesia Tanpa Pajak dan Utang, Bogor: Al-Azhar Press.

Kementerian Keuangan Republik Indinesia. 2014. Revisi APBN 2014 Ditujukan Untuk Fiskal yang Sehat. 
Analisis Normatif Kritis Kebijakan.....

http:/ /www.kemenkeu.go.id/Berita/revisi-apbn-2014-ditujukanuntuk-fiskal-yang-sehat. (Diakses 4 Juni 2014).

Matthews, M., Tolchinsky, P., Blanco, R., Atserias, J., Mika, P., \& Zaragoza, H. 2010. Searching through time in the New York Times. In Proc. of the 4th Workshop on Human-Computer Interaction and Information Retrieval.

Monzer, Kahf. 1994. Budget Deficit and Public Borrowing Instruments in An Islamic Economic Sistems. The American Journal of Islamic Social Sciences, 11.

Rivlin, A. M. 2012. Rescuing the Budget Process. Public Budgeting \& Finance, $32(3)$.

Shaviro, Daniel. 1997. Do Deficits Matter?, The University of Chicago Press, Chicago.

Subiyantoro, Heru \& Riphat, Singgih. 2004. Kebijakan Fiskal Pemikiran, Konsep, dan Implementasi, (Ed.2). Jakarta: Penerbit Buku Kompas.

Suhartono. 2011. Harmonisasi Peraturan Undang-Undang dalam Pelaksanaan Anggaran Belanja Negara (Solusi Penyerapan Anggaran Belanja Negara yang Efisien, Efektif dan Akuntabel). Tesis. Fakultas Hukum Program Pascasarjana Universitas Indonesia (UI).

Tempo.co. BISNIS. 2013. Kenaikan Harga BBM Diumumkan Jumat. http:// www.tempo.co/read/news/2013/06/20/090489858/KenaikanHarga-BBM-Diumumkan-Jumatm (Diakses 4 Juni 2014).

Zuhroh, I., \& Kaluge, D. 2012. Dampak Pertumbuhan Nilai Tukar Riil Terhadap Pertumbuhan Neraca Perdagangan Indonesia (Suatu Aplikasi Model Vector Autoregressive, Var). Journal of Indonesian Applied Economics, 1(1). 